\title{
Ravintoloiden ruokapalveluiden alv-alennus ja hintakehitys
}

\author{
Ari Peltoniemi ja Johanna Varjonen
}

Kuluttajatutkimuskeskus, PL 5,00531Helsinki, ari.peltoniemi@ncrc.fi,johanna.varjonen@ncrc.fi

\section{Tiivistelmä}

Ruokapalveluiden arvonlisävero aleni Suomessa vuoden 2010 heinäkuussa 22 prosentista 13 prosenttiin, joten elintarvikkeiden, mukaan otettavan eli take away-ruoan ja ravintoloiden ruokapalveluiden arvonlisävero on nyt samalla tasolla. Poliittisena päätöksenä tehdyn ruokapalveluiden veromuutoksen kautta haluttiin vaikuttaa kuluttajien ostovoimaan ja asettaa ruokapalveluiden myynti tasa-arvoisempaan asemaan kauppojen ateriamyynnin kanssa.

Euroopan unionin (EU) alueella ruokapalveluiden arvonlisäverokannat vaihtelevat kolmesta prosentista aina 25 prosenttiin saakka. Suomessa ruokapalveluiden alv-kanta on nyt lähellä unionin keskimääräistä tasoa, sillä vuoden 2011 alussa ruokapalveluiden keskimääräinen asukasluvulla painotettu verokanta oli 13,9 prosenttia EU:n jäsenmaissa.

Tutkimus selvittää ravintoloiden ruokapalveluiden hintojen kehitystä vuoden 2010 toukokuusta syyskuuhun eri puolilta maata kootun hintaseuranta-aineiston avulla. Tutkimuksessa tarkastellaan, miten arvonlisäveron alennus siirtyi ruokapalveluiden kuluttajahintoihin. Lisäksi ravintoloiden toteutuneiden hintamuutosten perusteella esitetään laskennallisia arvioita arvonlisäveron muutoksen välittömistä vaikutuksista ruokapalveluiden kysyntään.

Hintojen muutoksen selvittämistä varten ennen ja jälkeen arvonlisäveron muutoksen kerättiin yhteensä 2 058 hintatietoa 392 ravintolasta eri puolilta Suomea. Aluehallintovirastojen ja Ahvenanmaan valtionviraston tarkastajat keräsivät hintatiedot vuoden 2010 toukokuussa ja syyskuussa käymällä paikan päällä ravintoloissa. Tällä tavoin varmistettiin hintatietojen virheettömyys ja ajan tasalla oleminen.

Hintakeräykset osoittivat, että arvonlisäveron alennus laski ruokapalveluiden kuluttajahintoja koko toimialalla keskimäärin 4,1 prosenttia. Tämä merkitsee hintajouston perusteella 4,2 prosentin kasvua ruokapalveluiden kysyntään. Laskennallisesti välittöminä vaikutuksina ruokapalveluiden työpaikkojen kokonaismäärä kasvaisi tällöin noin 2200 kappaleella.

Arvonlisäveron alennus suirtyi ravintoloiden kuluttajahintoihin parhaiten ketjuihin kuuluvissa kahviloissa, liikenneasemaravintoloissa ja ketjupizzerioissa. Hinnat laskivat ainakin jonkin verran kaikissa ravintolatyypeissä lukuun ottamatta järjestäytymättömiä ketjuihin kuulumattomia pizzeriatyyppisiä ravintoloita. Niissä arvonlisäveron alennuksen vaikutuksen näkymättömyys voi johtua ainakin osittain siitä, että informaatio arvonlisäveron alentamisesta ei tavoittanut yrittäjiä tarpeeksi hyvin tai sitä ei osattu tulkita oikein.

Eri ravintolatyypit veivät arvonlisäveron alennuksen hintoihin parhaiten niissä ravintola-annoksissa, jotka edustavat kunkin ravintolatyypin ominta toiminta-aluetta. Esimerkiksi ketjukahviloissa alv:n alennus siirtyi erityisen hyvin kahvin, erikoiskahvin ja suolaisen kahvileivän hintoihin.

Asiasanat: ravintolat, ruokapalvelut, arvonlisävero, hintakehitys, kysyntä 


\section{Johdanto}

Euroopan unionin jäsenyyden alusta alkaen kaupoissa myytävien elintarvikkeiden ja ravintoloiden ruokapalveluiden arvonlisäverokannat olivat Suomessa eri tasoilla. Keskusteluissa ruokapalveluiden arvonlisäveron asettamista samalle tasolle kaupassa myytävän ruoan kanssa perusteltiin muun muassa sillä, että ruokapalvelut saisivat tasa-arvoisen aseman kauppojen ateriamyynnin kanssa. Kauppojen valmisruokatiskiltä ostettua ruokaa pidetään usein läheisenä substituuttina ravintolaruoalle, joten kuluttaja voi korvata ravintolassa nautitun annoksen kaupasta ostetulla ruoalla. Ruokapalveluiden arvonlisäverokannan laskemisen nähtiin olevan tärkeää ravintoloiden kilpailuedellytyksien ja työpaikkojen säilymiselle.

Vuoden 2009 kesäkuussa tuli voimaan direktiivi (Euroopan komissio 2009), jonka mukaan EU:n jäsenvaltiot voivat halutessaan soveltaa ruokapalveluihin yleisen arvonlisäverokannan sijasta alennettua arvonlisäverokantaa. Suomen hallitus päättikin vuoden 2009 elokuussa nostaa yleistä arvonlisäverokantaa yhdellä prosenttiyksiköllä vuoden 2010 heinäkuusta alkaen. Samanaikaisesti päätettiin käyttää uuden direktiivimuutoksen antamaa mahdollisuutta laskemalla ruokapalveluiden arvonlisäveroa yhdeksällä prosenttiyksiköllä 22 prosentista 13 prosenttiin. Siten vuoden 2010 heinäkuun alusta alkaen elintarvikkeiden, mukaan otettavan ruoan (take away -ruoan) ja ravintolaruoan alv on ollut samalla tasolla eli 13 prosentissa (HE 137/2009).

Ilman veroja yhden euron maksavan ruokapalvelun aiempi arvonlisäverollinen hinta ravintolassa oli yhtä kuin 1,22 euroa. Arvonlisäveron muutoksen jälkeen (1.7.2010) saman ruokapalvelun arvonlisäverollinen hinta ravintolassa on yhtä kuin 1,13 euroa.

Vastaavasti ilman veroja yhden euron maksavan take away -ruoan aiempi arvonlisäverollinen hinta ravintolasta ostettuna oli yhtä kuin 1,12 euroa. Arvonlisäveron muutoksen jälkeen (1.7.2010) saman take away -ruoan arvonlisäverollinen hinta on yhtä kuin 1,13 euroa.

Sekä ravintolassa nautitun ruoan arvonlisäveron alentamisesta seurannut hinnanalentamisvara että take away -ruoan arvonlisäveron nostamisen aiheuttama hinnankorotuspaine saadaan seuraavasti:

$$
\Delta=\frac{\mathrm{P}^{b}-\mathrm{P}^{a}}{\mathrm{P}^{a}} * 100
$$

jossa $\mathrm{P}^{a}$ viittaa kuluttajahintaan ennen arvonlisäveron muutosta ja $\mathrm{P}^{b}$ arvonlisäveron muutoksen jälkeiseen kuluttajahintaan.

Mikäli ravintolassa nautitun ruoan arvonlisäveron alennus olisi siirtynyt täysimääräisesti kuluttajahintoihin, olisi sen hinta alentunut seuraavasti:

$$
\frac{(1,13-1,22)}{1,22} * 100 \approx \bar{\top} 7,4 \%
$$

Mikäli take away -ruoan arvonlisäveron nousu olisi siirtynyt täysimääräisesti kuluttajahintoihin, olisi sen hinta noussut seuraavasti:

$$
\frac{(1,13-1,12)}{1,12} * 100 \approx 0,9 \%
$$

Ulosmyytävän ruoan eli take away -ruoan osuus ravintolaruoan verollisesta kokonaismyynnistä on Suomessa noin 10 prosenttia ja vastaavasti ravintolassa nautitun ruoan osuus noin 90 prosenttia (Ravintolaruokailun trenditutkimus 2008). Kun näillä prosenttiosuuksilla painotetaan arvonlisäveromuutosta seurannutta ravintolassa nautitun ruoan hinnanalentamisvaraa ja take away -ruoan hinnankorotuspainetta, saadaan ravintolaruoan keskimääräinen laskennallinen hinnanalentamisvara seuraavasti:

$$
((0,9 * \bar{\top} 7,4)+(0,1 * 0,9))=\bar{\imath} 6,6 \%
$$

Suomessa sekä poliittiset päätöksentekijät että kuluttajat ilmaisivat kiinnostuksensa siihen, miten ruokapalveluiden arvonlisäveron alennus siirtyy ravintolaruoan hintoihin. Julkisessa keskustelussa esitettiin näkemyksiä siitä, että ruokapalveluiden alv-alennuksen vaikutukset eivät siirtyisi hyvin kuluttajahintoihin.

Kuluttajatutkimuskeskus näki kuluttajan kannalta tärkeäksi tutkia veromuutospäätöksen vaikutuksia kuluttajahintoihin. Siksi se käynnisti vuoden 2010 keväällä ravintoloiden ruokapalveluiden 
hintaseurantatutkimuksen. Ensimmäinen hintakeräily toteutettiin ennen arvonlisäveron alennusta ja toinen hintakeräily veron alennuksen jälkeen.

Tässä tutkimuksessa selvitetään, miten arvonlisäveron alennus näkyi ruokapalveluiden hinnoissa keskimäärin ja millaisia eroja on esimerkiksi eri ravintolatyyppien sekä ravintola-annosten hintamuutoksissa. Lisäksi tehdään toteutuneiden hintamuutosten perusteella laskennallisia arvioita arvonlisäveron muutoksen välittömistä vaikutuksista ruokapalveluiden kysyntään.

\section{Aineisto ja menetelmät}

Tämän tutkimuksen menetelmä tarkastelee hintamuutosta painottaen kuluttajanäkökulmaa eli sitä, miten edustavia tutkimukseen mukaan tulevat ravintolat ovat kuluttajien kannalta. Tällöin ei pyritä suoraan satunnaisotantaan vaan lähtökohtana ovat erityyppiset ravintolat, esim. ruokaravintolat, pikaruokaravintolat, pizzeriat jne., joista kaikista pyritään saamaan mukaan otokseen edustava joukko ravintoloita. Valittu menetelmä antoi mahdollisuuden käyttää hyväksi aluehallintovirastojen asiantuntemusta kunkin paikkakunnan ravintolatarjonnasta sekä kerätä hintatiedot paikan päällä ravintoloissa. Painottamalla tuloksia kuluttajahintaindeksin käyttämän ravintolatyyppijaottelun mukaan saadaan tarkennettua tuloksia kuluttajien todellisen kulutuksen mukaiseksi.

Hintaseurantaa varten Kuluttajatutkimuskeskus jakoi ravintolat kahdeksaan eri ravintolatyyppiin: ruokaravintolat (a la carte ym.), henkilöstöravintolat, ketjuihin kuuluvat kahvilat, ketjuihin kuulumattomat paikalliset kahvilat, liikenneasemaravintolat (huoltoasemien yhteydessä toimivat ravintolat), ketjupizzeriat, ketjuihin kuulumattomat pizzeriat/kebap-ravintolat/etniset ravintolat, pikaruokaravintolat. Ravintoloiden tyyppijaottelussa käytettiin pohjana sekä Tilastokeskuksen kuluttajahintaindeksin (2008) hyödykeluokittelua että ravintolaruokailun trenditutkimuksen (2008) ravintolaluokittelua.

Kuluttajatutkimuskeskuksen näkökulmasta aluehallintovirastojen ja Ahvenanmaan valtionviraston tarkastajat tekivät eräänlaisen òkiintiöidyn otannanò, sillä Kuluttajatutkimuskeskus pyysi aluehallinnon edustajia valitsemaan kustakin ravintolatyypistä tietyn määrän paikallisesti tunnettuja ja kuluttajien suosimia ravintoloita hintaseurantaan. Kuluttajatutkimuskeskus käytti siten hyödyksi aluehallinnon tarkastajien niin asian- kuin paikallistuntemusta ravintoloiden lopullisessa valinnassa.

Ruokapalveluiden hintatietoja keräsivät käytännössä aluehallinnon tarkastajat ja pääkaupunkiseudulla lisäksi myös Kuluttajatutkimuskeskuksen tutkijat. Vain Kuluttajatutkimuskeskus ja aluehallinnon tarkastajat olivat tietoisia hintaseurantaan valittujen ravintoloiden nimistä ja hintakeräysten toteutusajankohdista.

Ensimmäisessä hintakeräyksessä oli mukana 399 ja toisessa 392 ravintolaa. Vertailukelpoisia hintahavaintoja oli yhteensä 2058 kappaletta, joten jokaisesta ravintolasta kerättiin hintatiedot keskimäärin noin viidestä erilaisesta ravintola-annoksesta. Riippuen ravintolatyypistä hintakeräyksen kohteina olevien ravintola-annosten lukumäärä oli vähimmillään neljä ja enimmillään kahdeksan.

Tämän tutkimuksen päätavoitteena oli ruokapalveluiden hintojen muutosten seuranta, mistä syystä oli tärkeää, että tuotteet pysyivät mahdollisimman samoina molemmissa hintakeräyksissä. Hintakerääjille toimitetussa tuotelistassa oli kuvaus kustakin hintaseurannassa olevasta tuotteesta eli ravintola-annoksesta. Ravintola-annokset olivat molemmissa hintakeräyksissä täysin tai mahdollisimman samanlaisia. Annosten vertailukelpoisuus eri ajankohtina varmistettiin valitsemalla yksilöityjä, tuttuja ravintola-annoksia. Jokaisessa ravintolatyypissä seurattiin siten useita kullekin ravintolatyypille ominaisia ravintola-annoksia.

Pistokokeet osoittivat, että Internetissä ilmoitetut hinnat eivät aina vastanneet paikan päällä ravintoloissa kerättyjä hintatietoja. Siksi lähes kaikista ravintoloista $(99 \%)$ hinnat kerättiin käymällä paikan päällä ravintolassa. Näin varmistettiin hintatietojen virheettömyys ja ajan tasalla oleminen.

Ruokapalveluiden kulutusosuuksilla painotetun hintamuutoksen laskemiseksi ravintola-annokset on jaettu Tilastokeskuksen kuluttajahintaindeksin $(2005=100)$ luokittelua käyttäen neljään ryhmään: ravintolaja kahvilaruoka, pikaruoka, henkilöstöravintolaruoka ja alkoholittomat juomat ravintoloissa. Tällöin saadaan laskettua koko ruokapalveluiden ryhmän painotettu keskimääräinen hintamuutos, jossa kuluttajanäkökulma on otettu hyvin huomioon.

Ruokapalveluiden hintamuutoksen laskemisessa voidaan käyttää vaihtoehtoisesti myös ruokamyynnin arvoja painoina. Ruokamyynnin arvojen käyttäminen anniskeluravintoloiden ruokapalveluiden hintamuutosten painotuksessa on parempi vaihtoehto kuin esimerkiksi liikevaihtotietojen käyttäminen. Tämä johtuu siitä, että liikevaihtoon sisältyy muun muassa alkoholin myyntitiedot. Tämän tutkimuksen käyttöön saatiin Valviralta vuoden 2009 ruokamyyntietoja (sisältää arvonlisäveron) niistä hintakeräyksen kohteina olleista ravintoloista, 
jotka kuuluivat anniskeluravintoloihin (Valvira 2010). Tällaisia anniskeluravintoloita hintakeräyksissä oli mukana yhteensä $163 \mathrm{kpl}$. Valviran antama ravintoloiden ruokamyynnin arvo koostuu arvonlisäveron alennuksen kohteina olleista ruokatarjoilusta ja alkoholittomista ruokajuomista (vesi, kotikalja, kahvi ym.). Ruokamyyntitietoihin ei kuitenkaan sisälly virvoitusjuomamyyntiä. Ruokamyynnin arvojen käyttäminen anniskeluravintoloiden ruokapalveluiden hintamuutosten painotuksessa tuo hyvää vertailutietoa ruokapalveluiden kulutusosuuksilla painotettuun hintamuutokseen.

\section{Tulokset ja tulosten tarkastelu}

Vertailukelpoisia verollisia hintahavaintoja kertyi yhteensä 2058 kappaletta. Hintaseurannan kulutusosuuksilla painotetut ruokapalveluiden hintamuutokset osoittavat, että vuoden 2010 heinäkuussa voimaan tullut ruokapalveluiden arvonlisäveron alennus laski kuluttajahintoja koko toimialalla toukokuun lopulla ja syyskuun alussa tehtyjen hintakeräysten mukaan keskimäärin 4,1 prosenttia. (taulukko 1). Tilastokeskuksen (2011) mukaan ruokapalveluiden kuluttajahinnat laskivat vuoden 2010 toukokuusta vuoden 2010 syyskuuhun noin 4,5 prosenttia ja yleinen kuluttajahintaindeksi nousi vastaavana ajanjaksona 0,5 prosenttia.

Taulukko 1. Hintakeräyksen kohteina olleiden ravintoloiden lukumäärä, hintahavaintojen lukumäärä, painotettu hintamuutos (\%) sekä toteutunut hintamuutos prosentteina hinnanalennusvarasta.

\begin{tabular}{|c|c|c|c|c|}
\hline & & & $\begin{array}{l}\text { Muutos 6,6 prosentin } \\
\text { hinnanalennusvarasta }\end{array}$ & $\begin{array}{l}\text { Muutos 7,4 prosentin } \\
\text { hinnanalennusvarasta }\end{array}$ \\
\hline 392 & Hintahavainnot, Ikm & Hintamuutos, \% & 62 & 55 \\
\hline
\end{tabular}

Ravintolassa nautitun ja ulosmyytävän (take away) ruoan keskimääräiseen laskennalliseen hinnanalennusvaraan $(6,6 \%)$ verrattuna kaikissa hintaseurannassa olleissa ravintoloissa hinnat alenivat koko ravintolasektorilla 62 prosenttisesti. Mikäli toteutuneita hinnan alennuksia verrataan vain ravintolassa nautittujen ruokapalveluiden laskennalliseen hinnanalennusvaraan $(7,4 \%)$, hinnat alentuivat koko toimialalla 55 prosenttisesti.

Tulosten mukaan arvonlisäveron alennus siirtyi kuluttajahintoihin vaihtelevasti eri ravintolatyypeissä. Koko toimialalla alennus siirtyi hintoihin parhaiten ketjuihin kuuluvissa kahviloissa

(i 5,1\%), liikenneasemaravintoloissa (ï 4,8 \%) ja ketjupizzerioissa (ï 4,7\%). Hinnat laskivat jonkin verran kaikissa ravintolatyypeissä lukuun ottamatta järjestäytymättömiä ketjuihin kuulumattomia pitserioita, joihin kuuluu myös kebab- ja etnisiä ravintoloita.

Ruokapalveluiden arvonlisäveron alennus näkyi eri tavoin erilaisten ravintola-annosten painottamattomissa hintamuutoksissa. Koko toimialalla jälkiruokien (ï 5,3 \%) ja pääruokien (ï 4,4 $\%)$ pääryhmissä alv:n alennus siirtyi parhaiten hintoihin. Vaatimattominta hintojen lasku oli virvoitusjuomien (ï 2,3 \%) pääryhmässä.

Ruokaravintoloissa (a la carte ym.) ja henkilöstöravintoloissa erityisesti pääruokien ja jälkiruoan hinnoissa arvonlisäveron alennus erottui parhaiten. Pääruokien hinnat alenivat ruokaravintoloissa keskimäärin noin 5,5 prosenttia ja henkilöstöravintoloissa keskimäärin 4,7 prosenttia. Jälkiruoasta kuluttaja maksoi arvonlisäveron alennuttua ruokaravintolassa keskimäärin lähes 6 prosenttia ja henkilöstöravintolassa 4,5 prosenttia vähemmän. Vähiten laski normaalikahvin hinta. Ruokaravintolassa sen hinta laski keskimäärin vain prosentin ja henkilöstöravintoloissa vajaan 3 prosenttia (taulukko 2). 
Taulukko 2. Eri ravintola-annosten painottamattomat hintamuutokset (\%) koko ravintola-alalla (kaikki) ja eri ravintolatyypeissä.

\begin{tabular}{|c|c|c|c|c|c|c|c|c|c|}
\hline & Kaikki & $\begin{array}{c}\text { Ruoka- } \\
\text { rav. }\end{array}$ & $\begin{array}{l}\text { Henkilöstö- } \\
\text { rav. }\end{array}$ & $\begin{array}{l}\text { Ketju- } \\
\text { kahvila }\end{array}$ & *Kahvila & $\begin{array}{l}\text { Liikenne- } \\
\text { asemarav. }\end{array}$ & $\begin{array}{c}\text { Ketju- } \\
\text { pizzeria }\end{array}$ & *Pizzeria & $\begin{array}{l}\text { Pikaruoka- } \\
\text { rav. }\end{array}$ \\
\hline Pääruoat & $-4,4$ & & & \multirow{10}{*}{$-3,5$} & \multirow{10}{*}{$-2,1$} & & & & \\
\hline Naudanliharuoka/sianliharuoka & & $-5,0$ & & & & & & & \\
\hline Kanaruoka & & $-5,0$ & & & & & & & \\
\hline Kalaruoka & & $-5,5$ & & & & & & & \\
\hline Pāăruokasalaatti & & $-6,0$ & & & & & $-6,3$ & , & $-4,7$ \\
\hline $\begin{array}{l}\text { Peruslounasateria } \\
\text { (lounaspaketti) }\end{array}$ & & & $-4,9$ & & & $-5,0$ & \multirow{7}{*}{$-3,3$} & & \\
\hline Lounaskeitto/lounassalaatti & & & $-4,5$ & & & $-5,4$ & & & \\
\hline Pizra (kehap/etninen) & & & \multirow{4}{*}{$-3,2$} & & & & & -7 & \\
\hline Hampurilainen & & & & & & & & & $-7,0$ \\
\hline Hampurilaisateria & & & & & & & & & $-4,7$ \\
\hline Suolainen kahvileipä & $-3,7$ & & & $-5,6$ & \multirow{2}{*}{$\begin{array}{l}-1,8 \\
-2,1\end{array}$} & $-5,5$ & & & \\
\hline Makea kahvileipä & $-3,6$ & & $-5,1$ & $-4,6$ & & $-3,8$ & & & $-1,8$ \\
\hline Virvoitusjuomat & $-2,3$ & $-4,2$ & \multirow{3}{*}{$-2,9$} & $-4,9$ & -3 & $-3,6$ & 1,7 & 1 & $-4,9$ \\
\hline Kahvi & $-3,6$ & -9 & & $-5,8$ & -.7 & $-5,1$ & $-12,1$ &,- 4 & \multirow[t]{3}{*}{$-4,0$} \\
\hline Erikoiskahvi & & $-3,5$ & & $-5,9$ & -9 & $-6,1$ & & & \\
\hline Jälkiruoka & $-5,3$ & $-5,8$ & $-4,5$ & & & & & & \\
\hline
\end{tabular}

* Ketjuihin kuulumattomat

Kaiken kaikkiaan eri ravintolatyypit veivät arvonlisäveron alennuksen ruokapalveluiden hintoihin parhaiten niissä ravintola-annoksissa, jotka edustavat kunkin ravintolatyypin ominta toiminta-aluetta. Esimerkiksi ruokaravintolat laskivat hyvin pääruokien ja jälkiruoan hintoja, mutta vähemmän kahvin hintaa. Ketjukahviloissa hinnat alenivat eniten kahvin ja erikoiskahvien sekä suolaisen kahvileivän hinnoissa, kun vastaavasti pääruokasalaatin hinta aleni vähiten. Pikaruokapaikoissa hampurilaisten hinnat alenivat reippaasti, mutta makeassa kahvileivässä hintojen lasku oli vähäistä.

Anniskeluravintoloiden ruokamyynnin arvolla painotetut ruokapalveluiden hintamuutosmuutosprosentit osoittavat, että hinnat laskivat kaikissa seurannassa olleissa anniskeluravintoloissa keskimäärin 4,9 prosenttia. Siten sekä kulutusosuuksilla että ruokamyynnin arvolla painotetut hintamuutokset osoittautuivat samansuuntaisiksi. Mikäli toteutuneita hinnan alennuksia verrataan vain ravintolassa nautittujen ruokapalveluiden laskennalliseen hinnanalennusvaraan $(7,4 \%)$, hinnat alentuivat kaikissa anniskeluravintoloissa 66 prosenttisesti.

\section{Suuntaa antavia arvioita ruokapalveluiden arvonlisäveron alennuksen välittömistä vaikutuksista ravintola-alan kysyntään}

Vuonna 2009 ravintola-alan kokonaismyynti oli noin 5,48 mrd. euroa (Valvira 2011). Tämän tutkimuksen mukaan ravintola-alan myynnistä ruokapalveluilla on laskennallisesti 72,2 prosentin osuus. Tätä prosenttiosuutta käyttäen voidaan arvioida, että ruokapalveluiden kokonaismyynti vuonna 2009 oli 3,96 mrd. euroa.

Kansantalouden tilinpidon mukaan vuonna 2009 majoitus- ja ravitsemistoiminnan työllisten eli työpaikkojen kokonaismäärä oli 80700 (Tilastokeskus 2011). Voidaan olettaa, että ravitsemistoiminnalla on koko majoitus- ja ravitsemistoiminnan työpaikkojen määrästä suunnilleen sama osuus (81 prosenttia) kuin henkilötyövuosissa mitattuna. Tällöin vuonna 2009 ravitsemistoiminnan työpaikkojen määrä oli 65367 $(0,81 * 80700)$. Ruokapalveluiden työllisyysosuuden arvioidaan tässä tutkimuksessa olevan noin 80 prosenttia. Tätä prosenttiosuutta käyttäen voidaan arvioida, että ruokapalvelut työllistivät $52294(0,8 * 65367)$ ravintolaalan työpaikkaa vuonna 2009.

Ruokapalveluiden osuutta ravintola-alan myynnistä ja työllisistä tarvitaan, kun hintajoustoja käyttäen lasketaan ruokapalveluiden arvonlisäveron alennuksen vaikutus alan myyntiin ja työpaikkojen määrään. Tässä tutkimuksessa on ruokapalveluiden hintajoustona käytetty Edgertonin ym. (1996) tutkimuksen mukaista tulosta (ï 1,02).

Tämän tutkimuksen hintaseurannan mukaan ruokapalveluiden arvonlisäveron yhdeksän prosenttiyksikön alennus aikaansai 4,1 prosentin hintojen alennuksen ruokapalveluissa. Asettamalla ruokapalveluiden hintajoustoksi ï 1,02 saadaan kysynnän kasvuprosentiksi 4,2. Tällöin 4,2 prosentin kysynnän kasvun näkyminen myynnissä ja työllisyydessä tarkoittaisi ruokapalveluiden kokonaismyynnin $(3,96$ mrd. euroa) lisäystä 166 miljoonalla eurolla ja vastaavasti ruokapalveluiden työpaikkojen kokonaismäärään (52 294) tulisi lisäystä 2196 kappaletta (taulukko 3). 
Taulukko 3. Ruokapalveluiden myynnin ja työllisten arvioitu lisäys, kun kysynnän kasvu on 4,2 prosenttia.

\begin{tabular}{|c|c|c|c|c|}
\hline & & & $\begin{array}{l}\text { Ruokapalveluiden kokonaismyynnin } \\
\text { ¿Hisäys, milj. euroa }\end{array}$ & $\begin{array}{l}\text { Ruokapalveluiden } \\
\text { työpaikkojen määrän lisäys }\end{array}$ \\
\hline$-1,02$ & $-4,1$ & Kysynnän kasvu, \% & 166 & 2196 \\
\hline
\end{tabular}

* Tässä laskelmassa käytetty ruokapalveluiden hintajousto on peräisin Edgertonin ja muiden (1996) tutkimuksesta.

\section{Johtopäätökset}

Hintaseurannan kulutusosuuksilla painotetut ruokapalveluiden hintamuutokset osoittavat, että vuoden 2010 heinäkuussa voimaan tullut ruokapalveluiden arvonlisäveron alennus laski kuluttajahintoja koko toimialalla toukokuun lopulla ja syyskuun alussa tehtyjen hintakeräysten mukaan keskimäärin 4,1 prosenttia.

Arvonlisäveron alennus siirtyi kuluttajahintoihin vaihtelevasti eri ravintolatyypeissä. Koko toimialalla alennus siirtyi hintoihin parhaiten ketjuihin kuuluvissa kahviloissa (ï 5,1\%), liikenneasemaravintoloissa (i 4,8 $\%)$ ja ketjupizzerioissa (ï 4,7 \%).

Pääosin eri ravintolatyypit veivät arvonlisäveron alennuksen hintoihin parhaiten niissä ravintolaannoksissa, jotka edustavat kunkin ravintolatyypin ominta toiminta-aluetta. Esimerkiksi ketjukahviloissa alv:n alennus siirtyi erityisen hyvin kahvin, erikoiskahvin ja suolaisen kahvileivän hintoihin.

Tutkimuksessa mukana olleiden anniskeluravintoloiden hintamuutosten painottaminen ruokamyynnin arvolla antoi samansuuntaisen, mutta hieman isomman hintamuutosprosentin $(4,9 \%)$ kuin kaikkien ravintoloiden hintamuutosten painottaminen kulutusosuuksilla. Tätä tulosta voidaan pitää odotettuna, sillä anniskeluravintoloiden joukossa on melko paljon ison ruokamyynnin omaavia ketjuihin kuuluvia ravintoloita, jotka ovat yleensä myös järjestäytyneitä.

Arvonlisäveron yhdeksän prosenttiyksikön alennuksesta seurasi tutkimuksen hintaseurannan tuottamien tulosten perusteella keskimäärin 4,1 prosentin lasku ruokapalveluiden kuluttajahintoihin. Tämä merkitsee 4,2 prosentin kasvua ruokapalveluiden kysyntään. Laskennallisesti välittöminä vaikutuksina ruokapalveluiden kokonaismyyntiin saadaan tällöin 166 miljoonan euron lisäys ja vastaavasti ruokapalveluiden työpaikkojen kokonaismäärään kasvua noin 2200 kappaleella.

Valviran mukaan anniskeluravintoloiden ruokamyynnin arvo kasvoi noin 4 prosenttia vuoden 2010 jälkimmäisellä puoliskolla edellisvuoteen nähden (Valvira 2011). Siten heti arvonlisäveron alennuksen jälkeen toteutunut anniskeluravintoloiden myynnin arvon kehitys tukee tämän tutkimuksen arviota siitä, että arvonlisäveron alennuksella oli ravintoloiden ruokapalveluiden kysyntään 4,2 prosentin välitön kasvuvaikutus.

Tutkimuksen yhteenvetona voidaan sanoa, että välittöminä vaikutuksina veronalennus siirtyi koko toimialalla ravintolaruoan ja alkoholittomien juomien asiakashintoihin kohtuullisesti. Ruokapalveluiden hinnat alentuivat järjestäytyneissä jäsenravintoloissa enemmän kuin järjestäytymättömissä ravintoloissa. Järjestäytyneen ravintolatoimialan veromuutoksen aktiivisella tiedottamisella ja kuluttajien, viestimien sekä tutkimuksen hintakehityksen seurannalla näyttäisi siten olleen myönteinen vaikutus alv:n alennuksen siirtymisessä ravintoloiden ruokapalveluiden hintoihin.

Ruokapalveluiden hintojen seuranta rajoittui tässä tutkimuksessa vuoden 2010 touko- ja syyskuuhun, joten arvonlisäveron alennuksen pidemmän aikavälin vaikutuksesta ruokapalveluidenkuluttajahintojen kehitykseen ei voida tehdä arvioita tutkimuksen tulosten perusteella.

On syytä olettaa, että mikäli yleisen taloudellisen tilanteen kohentuminen jatkuu, kuluttajat panostavat entistä enemmän ulkona ruokailuun. Arvonlisäveron alennuksen lisäksi myös muut seikat vaikuttavat ravintola-alan myyntiin ja työllisyyteen myönteisesti. Tällaisia kodin ulkopuolella tapahtuvan syömisen osuutta ruoan kokonaiskulutuksesta lisääviä tekijöitä ovat ainakin ruokailutottumusten muutokset, nuorempien ikäluokkien ulkona ruokailun yleisyys sekä yleinen elintason nousu. 


\section{Kirjallisuus}

Edgerton, D. L., Assarsson B., Hummelmose A., Laurila I. P., Rickertsen K. \& Vale P. H. (1996)

The Econometrics of Demand Systems. With Applications to Food Demand in Nordic Countries. Kluwer Academic Publishers.

Euroopan komissio (2009) Commisson Directive 2009/47/EC.

HE 137/2009. Hallituksen esitys.

Ravintolaruokailun Trenditutkimus (2008) TNS Gallup Oy.

Tilastokeskus (2008) Kuluttajahintaindeksi 2005 = 100. Käyttäjän käsikirja.

Tilastokeskus, tietokanta (2011) Kuluttajahintaindeksi, kansantalouden tilinpito, panos-tuotostaulukot, yritysrekisteri sekä majoitus- ja ravitsemistoiminnan tilinpäätöstiedot.

\section{Julkaisemattomat lähteet}

Valvira (2010) Anniskeluravintoloiden ravintolakohtaiset ruokamyynnin arvot vuodelta 2009.

Valvira (2011) Ennakkotieto anniskeluravintoloiden myynnin arvosta vuodelta 2010. 